\title{
Studie výuky dějepisného učiva na 1. stupni ZŠ ${ }^{1}$
}

\author{
Jana Stará, Karel Starý \\ Univerzita Karlova, Pedagogická fakulta \\ Redakci zasláno 16. 3. 2016 / upravená verze obdržena 4. 8. 2016 / \\ k uveřejnění přijato 29. 9. 2016
}

\begin{abstract}
Abstrakt: $V$ této stati představíme výsledky empirické studie výuky tématu událostí 17. listopadu 1939 a 1989 ve třetím ročníku ZŠ. Po krátkém ukotvení tématu v teoretickém rámci aktuálního vývoje dějepisného vzdělávání $\mathrm{v}$ primární škole $\mathrm{v}$ mezinárodním kontextu a popisu výzkumné metodologie seznámíme čtenáře s hlavními výzkumnými zjištěními. Kvalitativní explanatorní případová studie výuky tř̌i učitelek, založená na pozorování výuky, rozhovorech s učiteli a analýze písemných projevů žáků, prokázala, že žáci jsou již v primární škole schopni porozumět významu historických událostí a uvědomovat si hodnotu života ve svobodné společnosti. $\mathrm{K}$ tomuto výsledku mohou žáky učitelé dovést různými př́stupy, je však nutno respektovat vývojové schopnosti žáků a reagovat na specifická úskalí, která přináší dějepisné učivo. Patří mezi ně nároky na orientaci v časových obdobích, tendence přeceňovat roli známých osobností (personifikace) a posuzování historických událostí měřítky současnosti (prezentismus). Jako efektivní př́ístupy se ve studii ukázaly přístupy badatelsky orientované výuky - přístupy orální historie a př́ístupy založené na analýze hodnoty života ve svobodné společnosti na základě rozhovoru o prožitcích a pocitech lidí žijících $\mathrm{v}$ době nesvobody.
\end{abstract}

Klíčová slova: dějepisné vzdělání, soudobé dějiny, primární vzdělávání, př́ípadová studie

\section{Výuka dějepisu v primárním vzdělávání}

\subsection{Význam dějepisného vyučování}

Úloha dějepisného vzdělávání se v minulosti přirozeně měnila a vyvíjela se hlavně diskuse o jeho funkcích. Již od dob antického starověku se objevuje názor, že dějepisné znalosti nám pomáhají pochopit současnost. Výuka dějepisu je také tradičně vnímána jako prostředek výchovy $\mathrm{k}$ mravnosti, nástroj, který pomáhá při budování „lepší společnosti“ (od osvícenství). Od konce 18. století se ve školách začal výrazněji uplatňovat národní zřetel

1 Článek vznikl s podporou projektu GA ČR 15-19158S: Formativní hodnocení žáků prostřednictvím vzdělávacích cílu․

DOI: https://doi.org/10.5817/PedOr2017-1-6 
a úlohou dějepisného vzdělávání bylo formovat uvědomělé a hrdé občany. Postupně se v kurikulu mnoha zemí vyčleňuje jako samostatná složka sociálně-humanitního vzdělávání občanská výchova (např̀ v Nizozemsku v polovině 60. let 20. století), jinde zůstává občanská výchova přirozenou složkou dějepisné výuky. $Z$ tohoto shrnutí tradičních funkcí dějepisného vzdělávání je zřejmé, že výuka dějepisu je do značné míry nástrojem pro rozvoj hodnot a politického uvažování (Wils \& Verschaffel, 2012).

Soudí se, že školní dějepis společně s médii a politickým klimatem mají významný podíl na tom, jak žáci vidí sami sebe, své dějiny, svoji úlohu v regionech, národních pospolitostech či v internacionálním prostředí (Čapek, 2005). V primárním vzdělávání je dějepisné učivo obvykle integrováno do předmětu společně $s$ dalšími př́rodovědnými a společenskovědními obory (např. v Německu či v ČR), v některých zemích (např. Anglie) však tvoří dějepis samostatný předmět.

V západní a severní Evropě se od konce 70. let 20. století rozvíjí nové pojetí dějepisu (New history) vycházející z kritiky chronologického a na národní dějiny zaměřeného pojetí výuky. Začíná se zdůrazňovat historická metodologie ve výuce, žák se má učit historicky myslet, analyzovat a interpretovat historické skutečnosti, pracovat s historickými prameny apod. Výuka se věnuje ve značné míře sociálním a antropologickým dějinám a historii etnických minorit. Toto pojetí samozřejmě bojuje s některými obtížemi, mj. s nedostatkem času na takto pojatou výuku, požadavkem na nové koncipování učiva a jeho rozvrstvení mezi různé stupně vzdělávání, nedostatkem vůdčí linie historického výkladu, politickými kontroverzemi, které přináší pluralita názorů při výkladu národních dějin, požadavky vyšších stupňů škol na vědomosti žáků aj. V 80. letech ve Velké Británii dochází k další transformaci výuky dějepisu. Kritizováno je důsledné uplatňování multikulturního a antirasistického principu, př́klon k empatii, př́lišný důraz na sociální a hospodářské dějiny, nedostatečné pěstování britsko-anglické identity. Nicméně trvá důraz na badatelský př́ístup. Od 90. let minulého století narůstá v západních zemích důraz na rozvoj porozumění propojenosti světa. Některé vzdělávací systémy na základě toho koncipovaly pojetí dějepisu v jednotlivých stupních vzdělávání. Jako vyhovující se pro tyto účely jeví přístup, při němž se nejprve výuka zaměřuje na lokální záležitosti, pak na národní, posléze na evropské a celosvětové, přičemž vyšší stupeň vždy obsahuje i stupeň nižší (Čapek, 2005). Zároveň s tendencí globalizační se projevuje tendence diverzifikační v etnické, jazykové, kulturní, náboženské či státotvorné oblasti, a to ve vztahu mezi 
zeměmi, civilizacemi, kulturami i uvnitř jednotlivých zemí. Jde vlastně o úsilí v rámci globalizace zachovat historicky vzniklou silnou evropskou různorodost a vytvořit celek multikulturního, mnohonárodního a multijazykového společenství. Školní výuka nicméně zůstává stále zaměřena převážně na většinové obyvatelstvo každé evropské země a „stěží se v dějepisné výuce hledají reflexe etnické, kulturní a náboženské různorodosti uvnitř země, mezi regiony, v sousedních oblastech apod., tím spíše, že současné etnické či náboženské střety nevytvářejí prostor pro začínající zohledňování diverzifikace“ (Čapek, 2005, s. 222).

V USA a většině západoevropských zemí čerpá tradičně vzdělávání v primární škole $\mathrm{z}$ antropologie, sociologie, historie, ekonomie, geografie a politických věd, $v$ ČR hlavně $\mathrm{z}$ historie a geografie, ale v poslední době se začínají prosazovat i prvky dalších výše zmíněných disciplín (více o vývoji v Evropě a USA viz Dvořáková \& Dvořák, 2005). Diskuse se vedou o poměru zastoupení dějepisného učiva $\mathrm{v}$ rámci výuky ostatních společenskovědních témat v primárním vzdělávání. Někteří odborníci uvádějí, že dějepisné učivo je hodnotné především z důvodu poskytování znalostí, které umožní jedincům rozumět současnému světu (Brophy, Alleman, \& Halvorsen, 2013). Ztotožňujeme se se Z. Benešem (2009, s. 155), že „předmětem školního dějepisu není samotná historická skutečnost (žákovým úkolem není primárně poznat, ,jak to ve skutečnosti bylo'), ale je jím historické vědomí (tedy zjednodušeně to, jak to, co bylo, působí v současnosti, jak je minulé ,živým' rozměrem současnosti a jak implikuje budoucí)“.

\subsection{Vývojové předpoklady žáků 1. stupně ZŠ pro chápání dějepisného učiva}

I když je výuka dějepisného učiva pro děti mladšího školního věku náročná, dokáží porozumět obecným chronologickým sekvencím (např̀ vývoj dopravních prostředků) a historickým událostem (např. na základě příběhů lidí, se kterými se mohou identifikovat) nebo rozlišovat mezi událostmi dávné a méně dávné historie na základě srovnávání jednotlivých aspektů života lidí v různé době (napřs. bydlení, odívání, používání různých nástrojů apod.), i když nejsou schopny analyticky zacházet s abstraktními historickými pojmy a tématy (Brophy et al., 2013; Peck, 2005). Výzkumy Bartona a Levstikové (1996) ukázaly, že historická data nemají pro děti do 3. ročníku primární školy velký význam, ve 3. a 4. ročníku sice děti už rozumějí jejich číselné hodnotě, ale obvykle až v 5. ročníku dokážou data propojit s příslušnými souvisejícími kontextovými poznatky. 
Postupný vývoj historického vědomí u dětí mladšího školního věku:

1) Kauzalita historických událostí

Nejprve děti nevidí v historické kauzalitě žádnou logiku - události se podle nich dějí nezávisle na sobě. Když dítě pozná, že události mají nějaké příčiny, nejprve si to vykládá mechanicky, myslí si, že události jsou způsobeny bezprostředně předcházejícími událostmi a že se proto musely odehrát právě tak, jak se odehrály. Později děti začínají rozumět, že události mají různé příčiny, které často působí současně, chápou, že věci se vyvíjí různě, že rozdílné hodnoty mohou způsobit konflikt, že vliv má geografická poloha, kultura, politické klima nebo ekonomické podmínky, a také si uvědomují, že prríčiny některých událostí nemůžeme beze zbytku poznat.

2) Chronologický vývoj

Nejprve děti vnímají změny jako na sobě nezávislé, spíše než jako vývoj v řetězci příčin. Pak si naopak myslí, že všechno může být vystopováno zpět až k první příčině a že všechno, co se stalo v minulosti, je předchůdcem současnosti. Posléze začínají vnímat historický vývoj jako postupnou transformaci, uvědomují si, že jenom některé aspekty se mění a že změny mohou být zanedbatelné nebo naopak velmi radikální. Dochází k poznání, že kontinuální změna je univerzální a nevyhnutelná, ale že to nemusí být vždy změna k lepšímu.

3) Porozumění jednání lidí v minulosti

Zpočátku děti nejsou schopny vcítit se do lidí žijících v minulosti. Když se setkají s něčím, co si nedovedou vysvětlit, přejímají „blahosklonný“ přístup - že naši předci nebyli tak vyvinutí, jako jsou lidé dnes („byli ještě hloupí"). Později začínají chápat, že lidé v dřívějších dobách jednali z jejich perspektivy racionálně. Zpočátku přisuzují lidem stereotypní nebo neurčitou motivaci (může za to jeho náboženství; prostě byl takový), později jsou schopny přisuzovat lidem specifičtější motivy, ačkoli stále na události dějin nahlížejí z pohledu současného světa (prezentismus).

4) Historické prameny a badatelské metody

Nejprve žáci nezaznamenají, že si některé prameny vzájemně odporují, nebo nechápou, jak mohou existovat vzájemně si odporující prameny. Teprve později si začínají uvědomovat, že zdroje musí být analyzovány a že se historici musí při práci s daty řídit zásadami historické vědy. Tak vznikají obhajitelné 
interpretace, ale nikdy nejsou definitivní, protože se někdy objeví dosud neznámé prameny, které porozumění historickým událostem mohou posunout (Brophy et al., 2013).

\subsection{Didaktické př́stupy ve výuce dějepisu na 1. stupni ZŠ}

Současná didaktika zdůrazňuje klíčovou roli žákovských pojetí v procesu učení. Klasická teorie konceptuální změny považuje poznávání za vysoce organizované v teoriích, schématech nebo rámcích a usuzuje se, že dosavadní pojetí dítěte může být rázem nahlédnuto jinak a může být nahrazeno jiným. Druhá teorie konceptuální změny chápe dětské poznatky nikoli jako koherentní „prototeorii“, ale jako „ekosystém“ volně provázaných elementů, které se proměňují jen pozvolna, postupně (Dvořáková, 2012).

Pecková (2005) uvádí do souvislosti potřebu vycházet z žákovských pojetí $\mathrm{s}$ potřebou vycházet ve výuce dějepisu z pro žáky představitelných jevů. Doporučuje věnovat ve výuce nejprve pozornost tomu, jak lidé dříve žili, a potom pomoci dětem porozumět širším souvislostem, které tento způsob života utvářely.

V oborovědidaktické literatuře (např. Brophy et al., 2013; Levstik \& Barton, 2011; Peck, 2005) se zdůrazňuje důležitost budování badatelských dovedností žáků. Shromaždování materiálu, jeho třídění, základy historické kritiky a prezentace výsledků vlastní práce jsou nahlíženy jako stejně důležité součásti dějepisného vzdělávání jako osvojování vědomostí o minulosti.

Rozvoj žákovského porozumění historii může být podle Brophyho a kol. (2013, s. 103) podpořen zdůrazňováním vyšších hladin myšlení při diskutování o historických událostech (higher-order thinking). Děti při takových diskusích mohou pochopit některé zásadní myšlenky/generalizace, jako např. že konflikt typicky vzniká tam, kde skupiny soupeří o zdroje či moc nebo zastávají rozdílné hodnoty.

Přístup do značné míry eliminující hrozbu zneužití dějepisu pro manipulaci žáků a zároveň omezující přetěžování žáků nadměrným množstvím faktografických informací je př́stup zdůrazňující rozvoj historického vědomí žáků a užívání badatelských metod historické vědy pro konstruování historických znalostí - doing history (Peck, 2005). 


\section{Metodologie výzkumu}

\subsection{Volba výzkumného tématu}

Tématem naší studie je výuka dějepisného učiva v primární škole. Náš zájem o tuto problematiku pramení z přesvědčení, že dějepisné učivo má v kurikulu primární školy své opodstatnění. V souladu s výše uvedenými teoretickými zdroji spatřujeme největší potenciál dějepisného učiva v primárním vzdělávání v budování historického vědomí a v uvědomování si kulturních a společenských hodnot.

V RVP ZV (MŠMT, 2013, s. 40) je uveden očekávaný výstup „objasní historické důvody pro zařazení státních svátků a významných dnů“. Rozhodli jsme se zaměřit na Den boje za svobodu a demokracii (dále jen 17. listopad). Jako východisko jsme využili učebnici Prvouka pro 3. ročník ZŠ (nakl. Fraus), na jejíž tvorbě jsme se podíleli. Téma ze soudobých dějin je v učebnici prvouky nové, což poskytuje př́ležitost popsat jev dosud nezkoumaný. Cílem naší studie bylo zjistit, jak k výuce tohoto tématu přistupují různí učitelé a jaké konkrétní postupy volí, aby děti učivu dobře porozuměly.

\subsection{Výzkumný design}

Zvoleným výzkumným přístupem je design kvalitativní prípadové studie. Podle klasifikace případových studií se jedná o explanatorní případovou studii, která podává vysvětlení případu prostřednictvím analýzy příčinných řetězců s využitím vybraných teorií. Taková př́ípadová studie je vhodná především za podmínek, kdy je cílem odkrýt méně známé nebo dosud neznámé vztahy a struktury daného př́padu, analyzovat jejich charakter, identifikovat příciny a důsledky (Yin, 2005). Výše jsme uvedli teoretický rámec, ze kterého vycházíme a který použijeme pro interpretaci výzkumných zjištění. Zvoleným př́padem je jev, který jsme vymezili jako výuku tematického celku 17. listopad 1939/1989 ve 3. ročníku základní školy. Základní výzkumnou otázkou je: Jak učitelé v primární škole vyučují téma soudobé historie? Záměrem nebylo z tohoto př́padu zobecňovat, ale prozkoumat, jak může vypadat konkrétní podoba implementace tématu soudobých dějin do výuky.

\subsection{Konstrukce výzkumného vzorku}

Výzkumný vzorek účastníků byl konstruován záměrným výběrem. Zajímalo nás, jak přistoupí $\mathrm{k}$ výuce o 17 . listopadu vyučující s výrazně odlišnými 
vyučovacími styly. Vybrali jsme proto dvě učitelky, které absolvovaly stejné přípravné vzdělávání, mají podobné profesní zkušenosti a vyučují podobnou populaci žáků (dvě paralelní třídy v jedné škole) a přitom mají velmi odlišný přístup k vyučování. Styl první učitelky bychom podle Fenstermachera a Soltise (2008) mohli označit jako exekutivní, styl druhé jako facilitační. Do vzorku byla zařazena ještě třetí učitelka, která vyučuje odlišnou žákovskou populaci, s výukou má málo zkušeností a její vyučovací styl je dosud nevyhraněný. Záměrem zařazení této učitelky bylo získat další „triangulační" data a lépe pochopit data získaná od dvou předchozích učitelek. Se dvěma prvními učitelkami spolupracujeme jako s fakultními učitelkami, třetí ještě studuje a současně již pracuje jako učitelka. Vybírali jsme mladé učitele s krátkou délkou praxe, kteří události roku 1989 neprožili. Učitelky Eva a Lenka ${ }^{2}$ vystudovaly učitelství pro 1 . stupeň ZŠ na Pedagogické fakultě UK, učí na běžné nevýběrové pražské základní škole a obě nastoupily na tuto školu v závěru svého studia (obě dva poslední roky svého studia zároveň učily na ZŠ). Učitelka Týna studuje ve 4. ročníku př́ípravného vzdělávání a souběžně začala vyučovat v mezinárodní soukromé škole, kde se na výuce rovnou měrou podílejí rodilí mluvčí a čeští učitelé.

\subsection{Dílčí výzkumné otázky a použité výzkumné metody}

Výše uvedenou výzkumnou otázku jsme specifikovali do dílčích podotázek: Jaké cíle si učitelé ve výuce kladou? Jak zohledňují vývojová specifika dètí mladšího školního věku? Jaké vyučovací metody vybírají a jak svou volbu zdůvodňují? S jakými problémy se při výuce potýkají? Kromě otázek směřovaných na učitele nás také zajímalo, jak žáci porozumí vzdělávacímu obsahu. Těmto specifickým otázkám odpovídal výběr výzkumných metod: pozorování výuky, rozhovory s učiteli a analýza písemných projevů žáků. Na realizaci výzkumu se podíleli dva výzkumníci (spoluautoři této studie). Sběr dat jsme prováděli individuálně, všechny ostatní činnosti od projektování až po interpretaci výsledků jsme zpracovávali společně.

\subsection{Harmonogram výzkumu}

Nejprve jsme pozorovali výuku tématu 17. listopadu a pořídili jsme z ní videozáznam. Bezprostředně po poslední sledované hodině jsme s každou učitelkou provedli hloubkový rozhovor. Cílem dotazování bylo zjistit, jaké cíle učitelky při výuce sledovaly, jak se jim dařilo jich dosahovat, co podle nich

2 Jména účastníků výzkumu jsou anonymizována. 
dělalo žákům při učení potíže a čím si to vysvětlují. Dále jsme analyzovali produkty učení žáků - kresby, postery, plakáty, zápisy v sešitě apod. S odstupem jednoho roku jsme žákům zadali písemnou práci s cílem zjistit, co si o 17. listopadu jako Dni boje za svobodu a demokracii pamatují. Písemná práce se skládala ze dvou částí. První byla znalostní a druhá spíše postojová. Nejprve žáci přiřazovali letopočty k událostem, např. Vrátila se svoboda a demokracie - 1989; Na dlouhou dobu lidé ztratili svobodu - 1939. V druhé části bylo jejich úkolem pokračovat v nedokončených větách, např.:

„Od té doby si připomínáme 17. listopad jako důležitý den, protože...”

\subsection{Vyhodnocení a analýza}

Při analýze dat jsme v transkriptech rozhovorů, záznamů z hodin a písemných prací žáků nejprve identifikovali textové úryvky, jejichž obsah se vztahoval k položeným výzkumným otázkám. Následně jsme významové jednotky sdružovali do obecnějších (nadřazených) kategorií. Jako výchozí kategorie jsme použili koncepty z teoretického rámce (Brophy et al., 2013), např́íklad r̆azení dějinných sekvencí, personifikace dějin, narativita, zjednodušená kauzalita. Během opakovaného kódování dat se vstupní kategorie sytily různou měrou, transformovaly se a objevovaly se kategorie nové, např. angažovanost učitele, upřesňování odpovědí žáků, prevádění obsahů do dětského jazyka, vysoká očekávání, aktivita žáků aj.

Kategorie a textové sekvence jsme opakovaně pročítali, porovnávali a upravovali. Postupně tak vznikal soubor hierarchizovaných kategorií, ze kterého jsme sestavili srovnávací přehledovou tabulku a explanatorní schéma (viz níže). Výroky uváděné v textu jako přímé citace ${ }^{3}$ účastníků slouží jako „články řetězu“ spojujícího data a teoretické koncepty (Yin, 2005). Zdroje, které přinesly data o jednotlivých fázích výuky (včetně její př́ípravy a výsledků), ukazuje následující schéma.

3 Citace výroků jsou identifikovány podle př́íslušnosti ke třídám: AE (třída učitelky s přezdívkou Eva), AL (trrída učitelky s přezdívkou Lenka), ZT (tř́ída mezinárodní soukromé školy učitelky s přezdívkou Týna). 


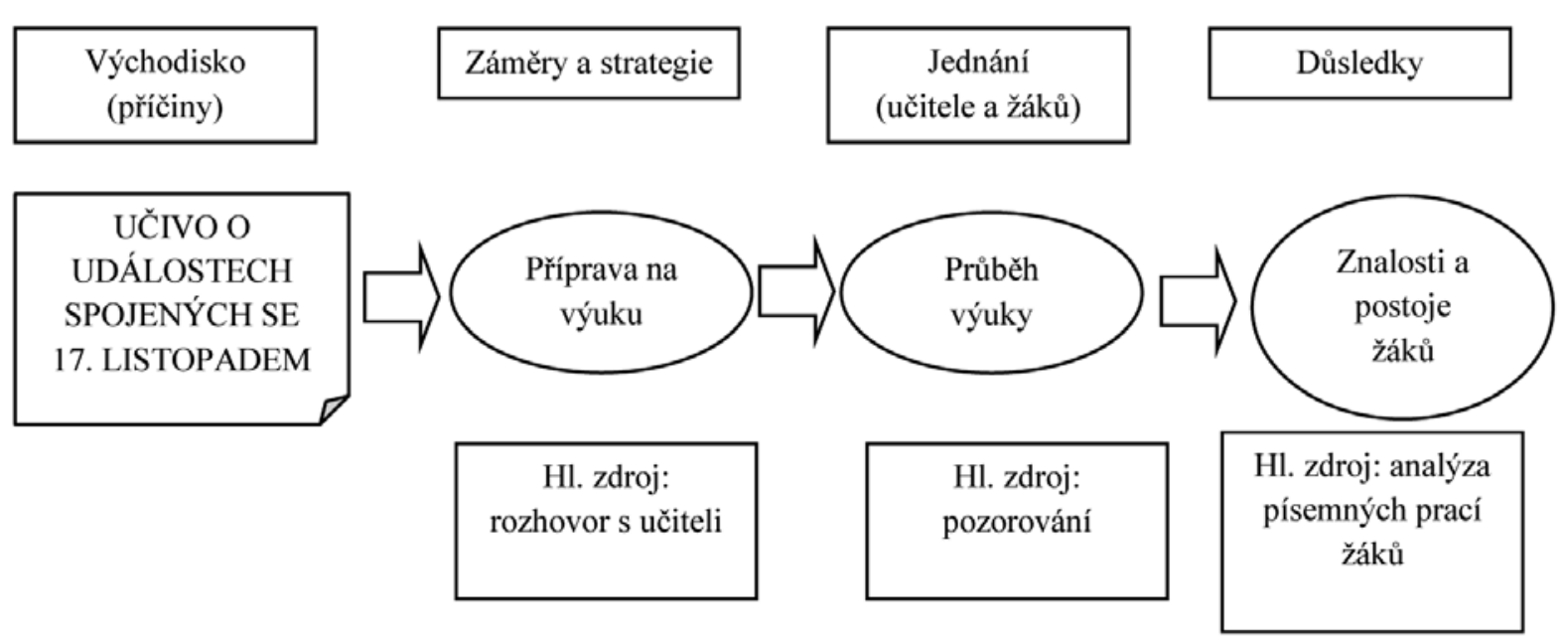

Obrázek 1. Zdroje dat v jednotlivých fázích výuky.

\section{Výzkumná zjištění}

V další části článku popíšeme nejprve různé přístupy, které zvolily učitelky zapojené do výzkumu, pak je porovnáme podle vybraných teoretických rámců s odkazy na reakce žáků.

\subsection{Odlišné př́stupy $k$ výuce tematického celku}

V této části nejprve naznačíme vyučovací styl každé učitelky, pak její cíle a strategické záměry a nakonec popíšeme hlavní proporce a obsah vyučovacích hodin.

\section{A. Exekutivní styl - Eva}

Pro exekutivní styl je charakteristické soustředění na učivo a vyučovací metody. Znamená to, že učitel za hlavní určující princip považuje to, aby si žáci z jeho výuky odnášeli co nejvíce informací. Neustále hledá a zdokonaluje vyučovací metody, které k tomuto cíli směřují (Fenstermacher \& Soltis, 2008).

Učitelka Eva se na výuku připravovala tak, že si přečetla doporučení v metodické př́ručce, a navíc konzultovala př́pravu s dějepisářkou z 2. stupně: „Ta mi radila, abych zůstala jen u událostí v roce 1939 a šla do hloubky." Navzdory doporučení se rozhodla učit o událostech 17. listopadu 1939 i 1989 současně s tímto zdůvodněním: „Myslím si, že pro mladší děti je důležitější, když dostanou události v celém kontextu, nějak se jim to přiblíží a nějak se v tom 
zorientují." Několik dní před touto hodinou dala Eva za úkol žákům zeptat se rodičủ či prarodičů doma na vzpomínky na 17. listopad 1989.

Tematickému celku byla vyhrazena jedna prodloužená vyučovací hodina (60 minut). Učitelka využívala učebnice prvouky, v níž jsou texty a obrázky popisující a ilustrující život v Československu ve 30. letech 20. stol., obsazení nacistickou armádou, poválečný život, období před rokem 1989 a události 17. listopadu 1989 (viz Prvouka 3; Stará, Dvořáková, \& Frýzová, 2009).

Žáci měli ve skupinách spojovat obrázky a slovní popisky, druhým úkolem bylo obrázky chronologicky seřadit. Úkol se projevil jako velmi náročný. Při kontrole splnění úkolu se ukázalo, že děti ke správnému řešení samy nedospěly. Dobíraly se jej s dopomocí učitelky, jednotlivé události se jim pletly, často neuměly na otázky učitelky odpovědět, část žáků během této dlouhé aktivity neudržela pozornost. Ve zbytku hodiny probíhal frontální rozhovor nad jednotlivými dějinnými sekvencemi. Eva zařadila do hodiny (v souladu s doporučením metodické příručky) také krátkou videoukázku vojenské přehlídky nacistické armády a proslovu A. Hitlera. Při výkladu postupovala Eva chronologicky. Když se přiblížila k roku 1989, zeptala se, co děti zjistily ve svých rodinách. Domácí úkol byl zadán jako dobrovolný, a tak reagovali jen někteří žáci a o zprostředkovanou výpověd' rodičủ se jednalo spíše výjimečně.

Jestli vám $\mathrm{k}$ tomu něco vaši rodiče řekli, jestli si to pamatují... nebo babičky a dědečkové. Že je zabili. ${ }^{4}$ To ses ptal doma, nebo si to myslišs? Myslím. A ty myslíš, Sárinko? Bud'to je zabili, nebo jim ublížili, nebo je odvezli na nějakou policejní stanici, kde prostě jim nadávali a bili a tak. A ty? Táta řek', že on natáčel v Karlovejch Varech a že pak se chystal jet zpátky do Prahy a pak mu děda volal, at' tam vůbec nejezdí, že je tam ta demonstrace a že tam jako všichni ti vojáci vběhli a rovnou je tam pobili všechny. (AE)

Z ukázky rozhovoru je patrné, jak je učivo pro žáky nesnadno pochopitelné. Je proto až s podivem, že někteří žáci prokázali schopnost se $\mathrm{v}$ událostech orientovat, a dokonce dospět k zobecnění propojujícím obě historické události: „Co mají společného tyto dvě události? Že protestovali studenti. To také a co ještě? Že ta zem nebyla svobodná."

Závěr hodiny ukazuje, že žáci jsou jistější v konkrétních představách než v použití abstraktních pojmů. Zároveň je ukázkou vedení frontálního rozhovoru se žáky s výraznou převahou promluv na straně učitelky.

4 Výpovědi žáků uvádíme pro lepší orientaci tučně. 
Takže my si připomínáme na tento den boj proti čemu? Proti svobodě. Je to... no, proti svobodě, jo? Myslíš, že budeme bojovat proti svobodě? Tento svátek má název Den boje za svobodu a demokracii. Za to, aby lidé mohli žít ve svobodném státě a aby tady byla demokratická vláda, což znamená co? Co to znamená, když žijete ve svobodě a demokracii? Kdo by to věděl? Co všechno se může dělat? Nebo naopak, když tady byl teda komunismus nebo tady byla německá armáda, tak co se nemohlo dělat? Odjíždět ze země. Takže když žijeme ve svobodě a demokracii, tak můžeme cestovat, nebo nemůžeme? Můžeme. Můžeme cestovat. Co dál? Co dál ještě můžeme všechno? Můžeme poslouchat hudbu, jakou chceme. Co dál? Můžeme nosit trička s obrázkama. Můžeme říkat svoje názory. Můžete třeba studovat školu, kterou si vyberete? Jo. Co ještě, máme tady třeba dostatek zboží? Nebo si nemůžeme vybrat zboží? Můžeme. Dobře, ufff. (AE)

\section{B. Facilitační styl - Lenka}

Pro facilitační styl je charakteristické soustředění na individualitu žáka a různé formy interakce. Takovému učiteli záleží na tom, aby poznal osobně každého žáka, jeho zázemí a možnosti, a snaží se jim vycházet vstř́íc. Individualizace výuky má své limity, a pokud se učitel snaží je překročit, může být frustrován nemožností toho dosáhnout. Při př́ípravě důkladně promýšlí, jak bude probíhat interakce mezi ním a žáky, dbá na to, aby se všichni žáci mohli vyjádřit, a rozvíjí interakci žáků mezi sebou (Fenstermacher \& Soltis, 2008).

Druhá učitelka vyhradila na tematický celek jednu vyučovací hodinu, a ještě část hodiny s několikadenním odstupem. Začala hodinu s žáky v kruhu na koberci diskusí o tom, co zjistili ve svých rodinách o životě v reálném socialismu a o listopadu 1989. Žáci do kruhu kladli donesené autentické předměty (odznak Občanského fóra, fotografie z dovolené v 80. letech v NDR, svazek klíčů apod.), naučné publikace či autorsky zpracované poznámky z rozhovorů $s$ rodiči a sdělovali své poznatky. Většina žáků měla vypsané informace na papíre, jedna dívka dokonce vytvořila tabulku, kde srovnala, co bylo „za vlády komunistů" a co je nyní. Povídání v úvodní části hodiny trvalo přes 20 minut, děti byly zaujaté, a kdyby učitelka diskusi důsledně nemoderovala, hovořily by o svých poznatcích určitě déle. $Z$ výroků je zřejmé, že si z domácího úkolu žáci odnesli mnohé informace a zaujetí pro problematiku (srovnej předchozí třídu $\mathrm{AE}$ ). Lenka poskytovala dětem dostatek prostoru k vyjádření, nepřerušovala je, neopravovala a za jejich (byt' neúplné či nepřesné) odpovědi je chválila. 
Tady mám obrázek klíčů, protože se šustilo těma klíčema... No, Viki? No takže, mně máma řikala, že na Václaváku se zvonilo klíčema, že už jako skončila vláda komunistů. Ano, hezky jsi to zjistila...Tak pokračujeme dál, Žofinka. Co jsi zjistila? Já jsem si udělala takovýhle plakát. Tady je to, co bylo předtím, a tady je, co bylo potom. To je nádherné, musím říct, Žofinko, že sis s tím opravdu dala práci. A vzala jsem si papírky a nalepila jsem tam, co se tady nesmělo a co je ted'ka jako lepší. A můžeš nám přečíst nějaký př́iklad alespoň? Co se nesmělo a co se ted' smí. Tak jo, vláda se nesmí kritizovat. Hmm, to bylo, a ted'? Můžeme dělat to, co nás baví. Dobře. Každý si může najít práci, jakou chce. Některé knihy se nesmí číst. Tak co z toho bylo to, co platí ted', a co platilo předtím? Z toho, co četla, poznali jste to? Ještě jednou to přečti, Žofinko. Některé knihy se nesmí číst. Některé knihy se nesmí číst, to platí ted', nebo to platilo předtím, Vašku? To platilo předtím. Ano, a jaké třeba knihy? No, to, co bylo ze Západu, nebo to, co bylo v Americe, ta strana která patřila k Americe, prostě se to nesmělo číst, o té svobodě v podstatě. Dobře, ano, děkuji za př́íklad... No, že třeba to ovoce z těch cizích zemí tam bylo předtím jenom o Vánocích a byly hrozný fronty, třeba na banány. Přesně tak, nebo na pomeranče. Nebo na mandarinky. Ano, to je pravda... Já jsem chtěl říct, že máma, když byla malá, tak viděli nějakýho chlapa, jak vlezl do tanku a chtěl přejet hranice. (AL)

Poté se žáci přesunuli do lavic a dostali nakopírované obrázky s popisky z učebnice. Obsahově se vztahovaly k životu v předválečném Československu a roku 1939. V textu byla vynechána slova a žáci měli za úkol (ve dvojicích) vymyslet, která slova tam patří. Poté proběhla společná kontrola.

Jejich život nebyl vždy snadný, ale přesto byl hezký. Další věta a kdo by už přibližně věděl, co tam doplnit, Ríšo? Naši obyvatelé byli... No, je to slovíčko, které znamená, že mohli dělat, co chtěli, mohli říkat, co si myslí, mohli cestovat. Co se tam hodí za slovo? Zino. Svobodný? Svobodní, přesně tak. A poslední věta, to mi přečte třeba Iva. Každého chránilo... Tak, co by tam tak mohlo být, no, co ty lidi chránilo, aby nevinní nebyli posláni do vězení, tak co myslíte, co se tam hodí za slovo? Svoboda? Hmm, to už jsme vyplňovali předtím, něco jiného. Něco, co vás chrání. Vás taky ted' něco chrání, třeba ve škole, máte určité svoje... Aničko. Právo. Právo, přesně tak. Každého chránilo právo. Nacisté uvěznili nebo zabili ty, kdo je neposlechli, a také... Někoho a Romy. Někdo by to možná mohl vědět, Zino, co myslíš? Romane? Židy a Romy. Židy a Romy, přesně tak. Odkud to víš všechno, Maxi? No, vim to, pamatuju si to. Já to odnikud nevim, já to prostě vim. Protože můj táta byl, teda můj děda byl v koncentračním táboře.

V další části hodiny učitelka Lenka pustila žákům úryvek z dokumentárního filmu o 2. světové válce, v němž pochodují němečtí vojáci, jsou slyšet výbuchy 
a střelba. Poté se žáků ptala, jaké pocity to $\mathrm{v}$ nich vyvolalo. Takto reagovala jedna žákyně: „Já jsem měla hrozný pocit a jsem ráda, že jsem se narodila před chvilkou a ne v té době, kdy to bylo."

V poslední části hodiny žáci pokračovali v doplňování chybějících slov. Tentokrát se texty a ilustrace vztahovaly k životu před rokem 1989 . Za domácí úkol přes víkend, jehož součástí byl státní svátek Den boje za svobodu a demokracii, zadala Lenka žákům úkol vytvořit plakát na téma Život před rokem 1989. V pondělním ranním kruhu děti ukazovaly své plakáty a hovořily o jejich obsahu.

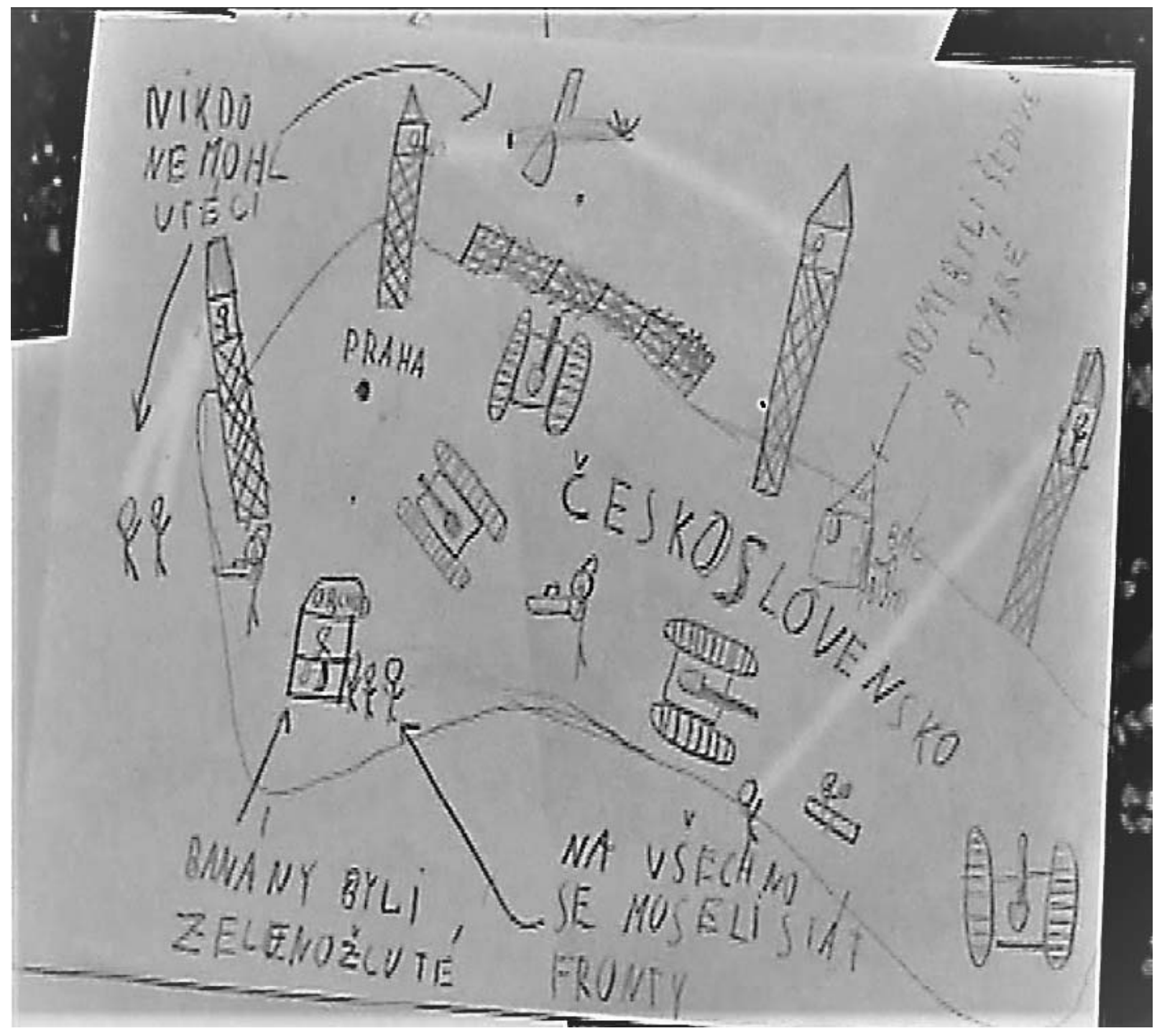

Obrázek 2. Plakát žáka 3. ročníku o životě před rokem 1989. 


\section{Nevyhraněný vyučovací styl - Týna (ZT)}

Učitelka Týna obsah tematického celku redukovala pouze na události 17. listopadu 1939. V rozhovoru uvedla, že je to proto, aby se události dětem nepletly, a že událostem roku 1989 se bude věnovat následující školní rok. Výuka probíhala frontálně a byla založena především na práci s učebnicí. Zvolený způsob práce stavěl žáky spíše do pasivní role, spontánně však vstupovali do učitelkou vedeného rozhovoru. Vzhledem k mezinárodnímu původu žáků se projevila potřeba obsah učebnice korigovat, což učitelka neprovedla.

Učitelka čte text z učebnice: „Většina z vašich prarodičů žila v předválečném Československu." Moje babička se jmenuje Lada a děda Kolja... To je rusky. Rusky, dobře. Tak, my ted'ka si přečteme o životě třeba zrovna těch vašich pradědečků a prababiček, když byli třeba stejně velcí, jako jste vy. Káto. Když byla válka, tak se jim narodilo miminko, na Sibiři se jim narodilo miminko a tam je zima. Glebe. Když můj pradědeček byl malej jako já, tak on jako, tam byla válka a ty Německo proti Bělorusku a oni potřebovali se schovat. $\mathrm{Hm}$, tak možná se o tom právě dočteme tady. Tak já poprosím Ivanku, jestli by začala číst. Paní učitelko, když moje babička byla malá a moje prababička a praděda, tak ti nacisté zavedli takové pravidlo, že vajíčka, mléko musely být jenom jejich, jenom státu... A oni to nemohli dostat... Tak, dycky museli za každý týden nasbírat dvě stě vajec... Danko. Ještě museli mít nějaký takový ty rolety, aby tam neviděli, že tam bylo rozsvíceno, protože tam viděli, že je rozsvíceno, takže by tam viděli lidi a zastřelili by je. Je to možné. Utíkali do sklepa a tam byli čtrnáct dnů a pak ještě, když jí byl jeden rok, tak tam jeli Němci okolo a všichni se šli schovat do místnosti pod zem, prostě taková halda, jak je třeba na zahradě, a byla tam díra a šli se schovat do tý díry, protože ti Němci by je zastřelili... A dyt' Rusko taky bylo s Němcema. Prosím? Rusko taky chvilku bylo s Němcema. Eh, ne, nebylo, nenene ${ }^{5}$. Tak, čteme dál...

Týna žáky často napomínala a linka frontálního rozhovoru tím byla přerušována. Na konci hodiny už žáci ve výuce téměř přebírali iniciativu. Během posledních šesti minut dostali za úkol nakreslit „něco k té době“. Někteří žáci s chutí začali kreslit, jiní vyjadřovali nesouhlas.

Mně se nechce kreslit. Tak napiš třeba nějaký vzkaz pro ty lidi, kteří byli stateční. Paní učitelko, můžu napsat vzkaz dědovi? Můžete. Jo, napiš tam vzkaz těm lidem, kteř́i byli stateční.

Žák má zřejmě na mysli tzv. Molotov-Riebentropův pakt o neútočení mezi Německem a Sovětským svazem, který však učitelka nezná. 


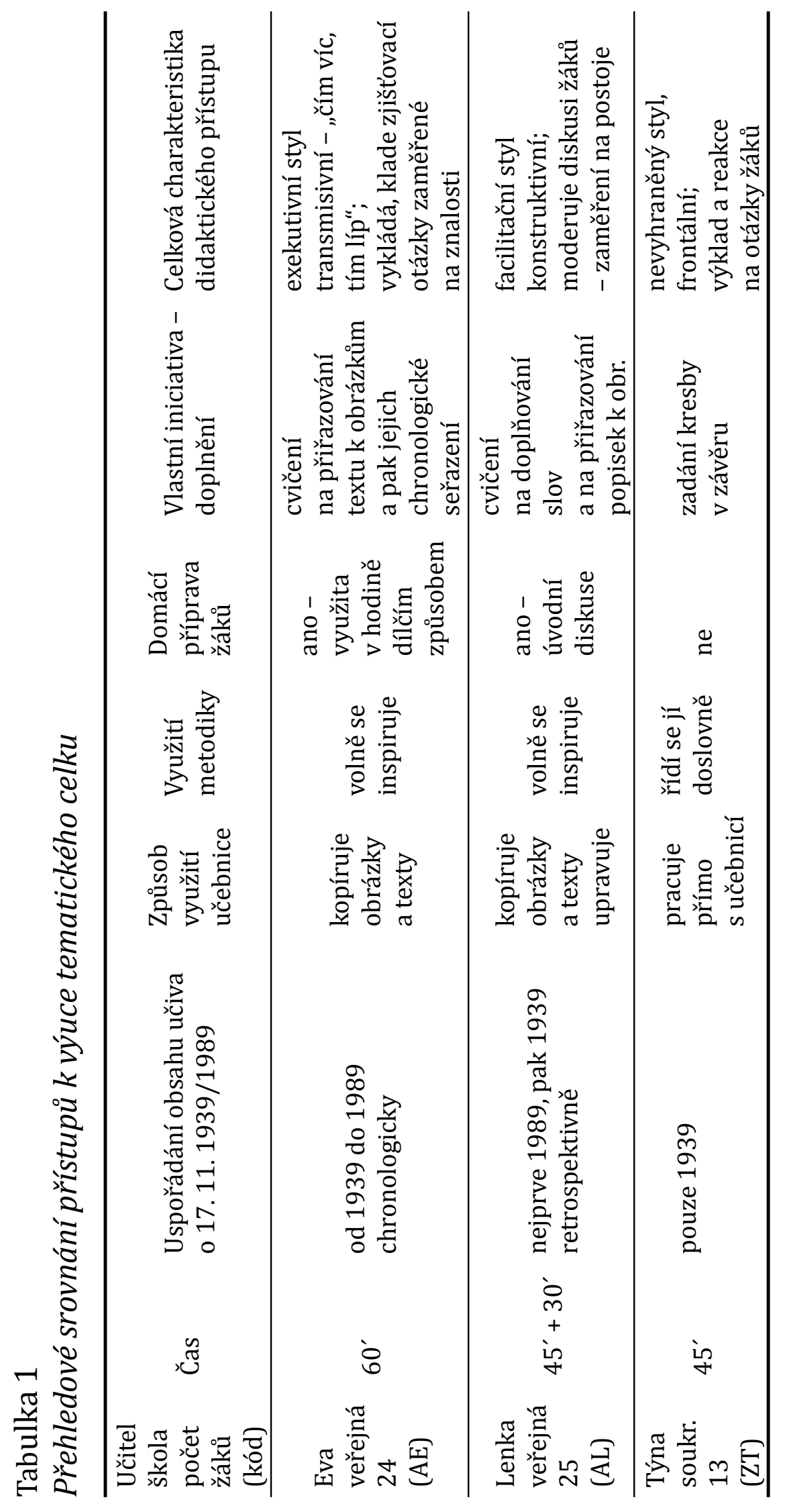




\section{Výběr výukového obsahu}

Všechny zkoumané učitelky došly k závěru, že rozsah učiva tematického celku je příliš velký na jednu vyučovací hodinu. Obě zkušenější učitelky (Eva a Lenka) na to zareagovaly tak, že čas navýšily. Lenka navíc zadala část obsahu jako domácí úkol (výroba plakátu). Týna se naopak rozhodla dodržet délku vyučovací hodiny a obsah redukovala na události roku 1939. To výrazně ztížilo žákům pochopení významu Dne boje za svobodu a demokracii.

\subsection{Tematická analýza např́ič různými vyučovacími přístupy}

V této části článku budeme porovnávat, jak se projevila různá témata napříč různými výukovými přístupy. Nejprve popíšeme práci s pojmy, pak se soustředíme na strukturaci učiva z hlediska časových a kauzálních hledisek. Dále se podíváme na to, jak se do výuky promítlo badatelsky orientované pojetí, a v závěru shrneme cíle, ke kterým výuka směřovala.

\section{Práce s pojmy}

Jedním z úskalí dějepisného učiva ve školním vzdělávání jsou abstraktní pojmy a množství pro žáky neznámých slov. Jejich přemíra činí text nesrozumitelný, na druhou stranu klíčové pojmy tvoří jádro vzdělávacího obsahu a bez nich lze jen obtížně pochopit smysl učiva. Ve zkoumaném tematickém celku lze za takový nezbytný pojem označit např́íklad demonstrace. Ve všech sledovaných hodinách byly pojmy vysvětlovány. Takto byl vysvětlen pojem okupant: „Když někdo obsadí cizí zemi, tak se mu říká okupant. Když někdo sebere zemi a nechá si ji pro sebe, řekne: ,ta bude moje ted'ka a mě budete poslouchat', to je okupant." (AE)

Učitelky většinou dobře identifikovaly, kterým slovům žáci nerozumí. Vyskytly se i případy, v nichž podnět vzešel od žáků a vysvětlení nebylo moc přesvědčivé.

Paní učitelko, co je ten tábor? Koncentrační tábor. Olivere. To je taková místnost... Nemusí to být místnost. No, to nemusí být místnost, to jsou prostě takový, to je takovej starej hodně domeček, takhle dlouhej jakoby a jsou tam ještě další, tam jim dávaj, tam právě Hitler zavíral prostě ty všechny lidi, kteří se jim nelíbí, a dávaj jim tam jenom chleba, suchej chleba jenom s vodou, nic víc. Takže víme, co je to tábor? A víme, co to znamená něco koncentrovat? Anglicky concentrate. Soustředit se? Jo, že třeba spojit dohromady, takže koncentrační tábor, tam shromaždovali lidi a někteří z nich pracovali a někteří z nich tam ale také umřeli. Protože dostávali strašně málo jídla, strašně málo pití, bylo jich tam 
hrozně moc. A co jejich rodiče? Ty tam byli třeba taky. Všichni ti, kteří se těm nacistům nelíbili, tak tam byli zavíráni. (ZT)

Problematické bylo vysvětlit pojmy, které žáci znají ze současnosti (demonstrace, komunisté) a neuvědomují si, že v textu se vyskytují v jiném (dobovém) kontextu. Specifický problém je s pojmy, které mají jiný význam v běžném jazyce a jiný v jazyce odborném - jako např́iklad slovo svoboda. U takových pojmů se může stát, že si žáci o vysvětlení neřeknou (protože je jim to „jasné") a je na učiteli, jak pojem ukotví a vybuduje.

\section{Strukturování učiva pomocí času}

Společenskovědní předměty mají volnější strukturu než předměty přírodovědné. Záleží tedy do značné míry na učiteli, zda v učivu logické uspořádání pro žáky nějak zvýrazní. U dějepisného učiva se nabízí učivo strukturovat chronologií. Chápání historického času je však pro žáky mladšího školního věku velmi obtížné.

Před chvilkou jsme si ř́kali, jestli se to teda lidem líbilo a jestli s tím byli spokojení, že nemohou cestovat, že tady nebyl dostatek zboží, že si nemohli ř́kat, co chtěli, nemohli vyjádřit nějaký svůj nesouhlas. Tak k čemu to vedlo? Kdopak by věděl? Že se pak ten Hitler... Už nejsme u Hitlera, ted'ka už jsme skončili válku, už jsme v České, teda Československé republice za komunistické vlády... (AE)

Doporučuje se klást důraz na znalost správné časové následnosti a nevyžadovat po dětech zapamatování velkého množství konkrétních časových údajů. Brophy a kol. (2013) uvádějí, že děti potřebují pomoci propojit historický obsah, kterým se zabývaly, s chronologickou perspektivou, a to např́klad tak, že událost zařadí do časové osy viditelné ve třídě, kam jsou aktuálně probírané historické události průběžně zařazovány.

Žáci přirozeně chápou sekvenčnost po sobě jdoucích událostí. Odpovídá to jejich zkušenosti s příběhy $\mathrm{v}$ umělecké literatuře, se kterými se setkávají $\mathrm{v}$ předmětu český jazyk. Mưže to ale také vést ke zjednodušenému chápání kauzality ve smyslu to, co predcházelo, způsobilo to, co následovalo. V př́padě tématu 17. listopadu 1939/1989 jsme zaznamenali tendence vykládat události roku 1989 jako důsledek událostí z roku 1939.

Historické události bývají v poslední době více žákům podávány s využitím dětské či historické beletrie, populárně naučných prací, novinových článků apod. V této souvislosti ve větší míře nabývají významu pocity, vcitování, 
mimovědecké poznatky, méně jsou tedy jako důležité vnímány racionalita a kritika (viz také Beneš, 2009). Přimět žáky k vcítění se do válečné doby, $\mathrm{k}$ vyjadřování jejich pocitů a $\mathrm{k}$ uvědomění si hodnoty života $\mathrm{v}$ míru měla učební úloha Zvuky doby (doporučovaná metodickou př́ručkou a realizovaná v nějaké podobě všemi sledovanými učitelkami). Barton \& Levstik (2004) uznávají důležitost vcitování se, ale podotýkají, že je nutné také rozvíjet porozumění různým perspektivám aktérů a dobovým kontextům.

\section{Narativní vnímání historie, hledisko multiperspektivity}

Vykládání historických událostí formou příběhu má své klady, které lze u mladších dětí dobře využít (Egan, 1982). Je však potřeba současně myslet na rizika, která to může přinášet. Jedním z nich je přehnaná personifikace dějin. Projevuje se tak, že děti přičítají odpovědnost za historické události jednotlivcům a přeceňují tak jejich úlohu. V našem př́padě jsme zaznamenali pokus vysvětlovat si 17. listopad jako boj Hitler kontra Havel.

Dalším z projevů zjednodušeného narativního vnímání je tendence nahlížet dějiny „černobíle“ jako boj „dobra a zla“. Učitel se tak pohybuje na tenkém ledě - na jednu stranu musí dějiny zjednodušovat, na druhou stranu by měl zjednodušení bránit. Mnoho historických událostí nemá jednoznačné vyznění, a pokud je zjednodušíme, můžeme se dopustit výrazné dezinterpretace.

V tematickém celku o 17. listopadu se autoři učebnice pokusili zmínit i některé pozitivní rysy období před rokem 1989. Sledované učitelky to uvedly okrajově nebo vůbec. Zajímavé bylo sledovat, jak odpovídali žáci v písemné práci. Na nedokončený výrok „Některým se před 1989 líbilo, že...,, odpovídali: nebylo tolik vrahů a zlodějů a byl větší klid... každý měl práci. Proto žádní bezdomovci nebyli... mohli být v komunistické straně... jsou komunisti oni sami..., které pocházejí téměř výhradně z rozhovorů s rodiči. Jedna dívka poukázala i na to, že její rodiče hodnotí období socialismu ambivalentně a poukazují na mnohé výhody, které jim toto období přineslo. Děti se tak autenticky setkaly s tím, že stejnou událost mohou hodnotit lidé různě, a to je z hlediska tzv. teorie multiperspektivity neboli mnohostranného výkladu dějin žádoucí (Stradling, 2003).

\section{Badatelsky orientovaná výuka}

Jako prevence zkresleného pohledu na historické události se v zahraničí rozvinul koncept badatelsky orientované výuky - doing history (Levstik \& Barton, 2011). Žáci se seznamují s postupy historické vědy a sami si 
zkoušejí pracovat jako historici. Cílem není z nich dělat jakési „malé vědce“, ale zprostředkovat jim, jak kriticky posuzovat historické prameny, jak odlišovat fakta od interpretací, jak vysvětlovat různé pohledy účastníků apod.

V našem případě tématu ze soudobých dějin se nabízelo vyzkoušet výzkumné postupy orální historie. $\mathrm{V}$ učebnici je zařazen text pamětníka událostí v listopadu 1939 a v metodické př́ručce je doporučení, aby žáci vyzpovídali své rodiče jako „pamětníky“ listopadových událostí roku 1989. V případě Lenky se ukázalo použití badatelské metody jako reálné a přínosné.

\section{Cíle výuky a jejich naplňování}

Všechny učitelky v rozhovoru uvedly, že věnovat se dějepisnému učivu v primární škole považují za důležité. Přesvědčivě argumentovala i nejméně zkušená Týna:

Myslím, že moderní dějiny nejsou dostatečně vyučovány. Udělají si v tom jasno, proč zrovna ten den nejdou do školy. A taky jim to pomůže pochopit, o čem se baví dospělí, napřs. komunismus. (ZT)

Pro daný tematický celek jsou v metodické př́ručce uvedeny tyto cíle:

1) Žák oceňuje svobodu a právní řád jako důležité hodnoty.

2) Žák uvede př́klad kladného i záporného jevu spojeného s obdobím vlády komunistů.

3) Žák uvede alespoň jeden $\mathrm{z}$ důvodů slavení Dne boje za svobodu a demokracii.

První cíl je afektivní a další dva kognitivní. Vzhledem k tomu, že žádná z učitelek cíle explicitně žákům nesdělila, pokusíme se odvodit, jaké cíle sledovaly, $\mathrm{z}$ jejich reflexe a průběhu hodin. $V$ rozhovorech se všechny učitelky podobně vágně vyjádřily, že jim jde hlavně o to, aby děti získaly všeobecný přehled, podle jejich slov tedy sledovaly rovinu především kognitivní.

Eva ve výuce opakovaně poukazovala na letopočty 1939 a 1989, neustále uváděla souvislosti mezi nimi a snažila se je ukotvit v historickém kontextu, což působilo spíše kontraproduktivně:

To bylo to, co mě zarazilo, že ty děti se neorientujou... S tím jsem nepočítala... Když jsme si to vysvětlili, tak pak už to nějak zvládly, ale dost mě překvapilo, že to bylo pro ně tak těžký, že to tak dlouho trvalo... Překvapilo mě, že vůbec neměly vhled, ani trošku do první republiky ani do druhé světové války. (AE) 
Lenka měla menší ambice, které se s ohledem na věk dětí jeví jako přiměřenější, a také zmínila přesah mimo školu:

Dostali takový všeobecný rozhled. Aby měli aspoň trošku povědomí o tom, co se stalo. Aspoň trošku. Aby si řekli: „Dneska je volno, to je kvůli tomu.“ No a taky, aby se mohli o tom bavit s rodiči. (AL)

Týna vyjádřila, že jejím cílem bylo, aby děti „pochopily souvislosti a co to znamená demonstrovat, že když se spojí v boji proti něčemu, proti společnému nepř́iteli, tak to jde, když budou schopni obhájit si svůj názor, podložit ho něčím." (ZT)

Ač byly ambice učitelek a cesty $\mathrm{k}$ jejich naplnění relativně odlišné, je zajímavé, že ve všech třídách se našlo srovnatelné množství žáků, kteří prokazovali dobré porozumění tématu a $\mathrm{v}$ písemné práci formulovali výstižné odpovědi, např: V listopadu 1939 lidé pocitovali... strach; úzkost; smutek; utrpení. Chtěli, aby... přežili; skončila válka; byla svoboda. V listopadu 1989 lidé... nechtěli komunisty; chtěli být demokratický stát; chtěli cestovat; chtěli svobodu. Demonstranti chtěli, aby... si mohli zvolit, koho chtějí; skončila vláda komunistů; žili ve svobodným státě; chtěli svobodu a práva; aby mohli svobodně žít. Demonstrace v roce 1989 nakonec vedly k... demokracii; svobodě; pádu komunistü; rozpadu komunismu.

Ve třídách Evy a Lenky však bylo i značné množství žáků, kterým se události pletly (viz výše), a jejich znalosti nebyly vzhledem $\mathrm{k}$ cílům hodiny dostatečné.

Co se týče afektivních cílů, ani jedna z učitelek je v rozhovoru a ve výuce explicitně neuvedla, ale všechny zařadily nějakou variantu aktivity Zvuky doby, která k uvědomění si hodnot svobody a demokracie přímo směřuje. V žákovském testu žáci všech zkoumaných tříd odpovídali tak, že můžeme říci, že afektivního cíle uvedeného $\mathrm{v}$ př́ručce bylo u většiny $\mathrm{z}$ nich dosaženo: 17. listopad je důležitý, protože... začala svoboda; máme svobodu; jsme svobodní; žijeme v demokratickém státě; jsme vyhráli nad komunismem; lidé mají demokracii zpět a mohou cestovat. Já osobně si myslím, že... to muselo být strašné pod vládou komunistů; nechtěla bych, aby mi např. vzali koně a dali ho do nějaké společné stáje a já bych se s ním ani nemohla setkat; si myslím, že komunisté by už neměli vládnout; obdivuju ty lidi, co se vrhli do ulic a demonstrovali; nechci, aby se to znova stalo; si myslím, že je to hodně významný rok, protože jsme dostali svobodu; si myslím, že je to pro ČR a Slovensko velmi důležitá událost, protože začala nová doba; nechci, aby se to opakovalo. 
$\mathrm{Na}$ životě v komunistickém Československu se jim (lidem) nelíbilo, že... je špehovali; nemohli vyjádřit, co si myslí; neměli svá práva. A musili se ř́ldit nesmyslnými pravidly; jim berou majetek a rozhodují o nich; bylo bezpráví; nemohli svobodně volit; nemohli jezdit do zahraničí; zakazovali vydávat knihy; trestali nevinné lidi.

\section{Závěry}

Zařazení tématu ze soudobých dějin do učebnice prvouky pro 3. ročník se projevilo jako nosné. Učebnicové zpracování se ukázalo jako př́liš rozsáhlé pro jednu vyučovací hodinu. Obsahuje obrazový a textový materiál, který všechny učitelky využily. Z metodické př́ručky zaujalo učitelky doporučení využít audio/video techniky a pustit žákům tzv. Zvuky doby. Tato skutečnost svědčí o přitažlivosti učebních úloh zdůrazňujících vcitování se do lidí a vyjadřování pocitů, které v žácích historické události vyvolávají (srov. Barton \& Levstik, 2004; Beneš, 2009 - viz výše).

Jako určující pro výběr obsahu i metod se jeví vyučovací styl učitele. I když byly přístupy učitelek různé, i s ročním časovým odstupem prokázali žáci relativně dobré znalosti. ${ }^{6} 0$ uvědomování si a oceňování hodnoty života ve svobodné společnosti svědčí odpovědi na nedokončené věty (viz výše).

Z doporučených didaktických př́stupů se ukázaly silné i slabé stránky narativního př́stupu a jako velmi funkční se ukázalo použití badatelské metody orální historie - rozhovoru s pamětníky.

Tato studie naznačuje se, že v dějepisném učivu není jednoduché respektovat vývojové zvláštnosti a snadno může docházet ke (zbytečnému) kognitivnímu přetěžování. Jako velké riziko spatřujeme tendenci učitele „předbíhat“ vývoj a zahrnovat žáky množstvím informací, se kterými se budou setkávat ve vyšších ročnících, aniž by učitel přizpůsoboval učivo schopnostem žáků. I když je obsahová vyprázdněnost stejně velkým rizikem jako př́lišné množství informací. Domníváme se, že prezentovaná studie poukazuje na potřebu zkoumat myšlenkové procesy tvořícího se historického myšlení žáků mladšího a středního školního věku, teprve se konceptuálně seznamujících s dějinami.

6 Ve znalostní části písemné práce v obou třídách AE a AL dosáhlo úplné správnosti odpovědí přes 60 \% žáků. U ZT byly výsledky pravděpodobně ovlivněny tím, že písemnou práci dostali žáci bezprostředně po výuce o 17. listopadu 1989. Možné je také to, že úspěšnost ovlivnilo složení žáků v této soukromé mezinárodní škole. V této tř́idě se úspěšnost blížila $90 \%$. 
Jako nosné se ukázalo více stavět na prožitku a směrovat výuku k afektivním cílům. Také by se jistě stálo za to zabývat $\mathrm{v}$ dalších výzkumech tím, k jakým vzdělávacím výsledkům vedou prožitkové přístupy ve výuce dějepisného učiva v primární škole. Výsledky těchto výzkumů by mohly být konfrontovány s názory učitelů a didaktiků dějepisu na poslání dějepisného vzdělávání v primární škole.

Smyslem dějepisné výuky není podle mnohých z nich učit o dějinách, ale prostřednictvím dějin učit chápat svět, ve kterém žijeme (Beneš, 2009). Jako hlavní účel dějepisného učiva v primární škole se nabízí možnost zprostředkovat význam klíčových společenských hodnot. $\mathrm{V}$ hodinách zkoumaných $\mathrm{v}$ rámci studie šlo o hodnotu života ve svobodné společnosti. Pro generaci dnešních dětí se jedná o takovou samozřejmost, až ji to může činit „neviditelnou“. I dnes jsou však občanské a lidské svobody ohrožovány. Někdy okolnostmi novými, daleko častěji však podobnými hrozbami jako v minulosti. $\mathrm{K}$ tomu, aby i budoucí generace dokázala svobodu a další občanské a společenské hodnoty vyznávat a hájit, může primární vzdělávání významně přispět. Zkoumat výsledky vzdělávání v afektivní oblasti je jistě velkou výzvou pro oborovědidaktický výzkum (některé informace o výsledcích starších žáků nám v této oblasti přináší např. studie občanské výchovy IEA, ${ }^{7}$ do které byla zapojena i Česká republika), nicméně jsme přesvědčeni o tom, že by se tímto směrem měl výzkum v budoucnu také ubírat.

\section{Literatura}

Barton, K. C., \& Levstik, L. S. (1996). „Back when God was around and everything“: Elementary children's understanding of historical time. American Educational Research Journal, 33(2), 419-454.

Barton, K. C., \& Levstik, L. S. (2004). Teaching history for the common good. Mahwah: Lawrence Erlbaum.

Beneš, Z. (2009). Základ a aplikace. Dějepis mezi historickou vědou a školním vzděláním. Pedagogika, 59(2), 153-163.

Brophy, J. E., Alleman, J., \& Halvorsen, A. L. (2013). Powerful social studies for elementary students. Belmont: Wadsworth Cengage Learning.

Čapek, V. (2005). Některé mezinárodní projekty a koncepce dějepisu ve škole. Acta Historica Neosoliensia. Ročenka Katedry histórie Fakulty humanitných vied Univerzity Mateja Bela v Banskej Bystrici, 2005(8), 217-239. Dostupné z www.ff.umb.sk/app/cmsSiteAttachment. php?ID $=438$

7 Dostupné na http://www.iea.nl/cived.html 
Dvořáková, M., \& Dvořák, D. (2005). Společenskovědní vzdělání. In V. Spilková (Ed.), Proměny primárního vzdělávání (s. 209-223). Praha: Portál.

Dvořáková, M. (2012). Př́prava studentů primární pedagogiky ke konstruktivistickému pojetí učiva a vyučování o společnosti (Disertační práce). Praha: Pedagogická fakulta Univerzity Karlovy v Praze.

Egan, K. (1982). Teaching history to young children. Phi Delta Kappan, 63(7), 439-441.

Fenstermacher, G. D., \& Soltis, J. F. (2008). Vyučovací styly učitelů. Praha: Portál.

Levstik, L. S., \& Barton, K. C. (2011). Doing history: Investigation with children in elementary and middle school. New York: Routledge.

Peck, C. (2005). Introduction to the special edition of Canadian social studies: New approaches to teaching history. Canadian Social Studies, 39(2).

MŠMT ČR. (2013). Rámcový vzdělávací program pro základní vzdělávání. Praha: MŠMT ČR. Dostupné z http://www.nuv.cz/file/318/

Stará, J., Dvořáková, M., \& Frýzová, I. (2009). Prvouka 3. Učebnice. Plzeň: Nakladatelství Fraus.

Stradling, R. (2003). Multiperspectivity in history teaching: A guide for teachers. Štrasburk: Council of Europe. Dostupné z http://www.coe.int/t/dg4/education/historyteaching/ Source/Notions/Multiperspectivity/MultiperspectivityEnglish.pdf

Wils, K., \& Verschaffel, T. (2012). Longing for the present in the history of history education. Paedagogica Histórica, 48(6), 793-799.

Yin, R. K. (2005). The case study research. Design and methods. Thousand Oaks: Sage.

\section{Autoři}

PhDr. Jana Stará, Ph.D., Univerzita Karlova, Pedagogická fakulta, Katedra primární pedagogiky, M. D. Rettigové 4, 11639 Praha 1, e-mail: jana.stara@pedf.cuni.cz

PhDr. Karel Starý, Ph.D., Univerzita Karlova, Pedagogická fakulta, Ústav výzkumu a rozvoje vzdělávání, Myslíkova 7, 11000 Praha 1, e-mail: karel.stary@pedf.cuni.cz

\section{Teaching history in primary education}

Abstract: In this paper we will introduce the results of the empirical study that deals with school instruction in the third grade of elementary school regarding the events of the $17^{\text {th }}$ November in 1939 and 1989. First, we put the topic in the context of the theoretical framework of the current international development of history education in primary schools, this will be followed by the description of the research methodology. Afterwards, we will introduce the main research findings. The qualitative, explanatory case studies of three teachers based on observations of their instruction, interviews with them, and analyses of written products made by pupils have shown that primary school age pupils are able to comprehend the meaning of historical events and values of life in a free society. Teachers can achieve these results by vari- 
ous means. However, they need to respect the developmental abilities of pupils and respond to specific demands connected with the history subject matter. These include the demands to grasp time periods, tendency to overestimate the role of well-known personalities (personification) and to introduce present-day ideas and perspectives into depictions or interpretations of the past (presentism). The study showed that the most effective methods are enquiry-based education methods, such as the oral history approach, and methods based on analyses of the free society life values including interviews in which people who lived in the times of oppression talked about their experiences and feelings.

Keywords: history education, contemporary history, primary education, case study

Zounek, J., Šimáně, M., \& Knotová, D. (2017). Socialistická základní škola pohledem pamětníků: sonda do života učitelů v Jihomoravském kraji. Praha: Wolters Kluwer.

Kniha si klade za cíl uchovat pamět’ na školu a život učitelů základních škol zejména před rokem 1989, a to prostřednictvím několika rozhovorů, které realizovali autoři v rámci tříletého výzkumu. Kniha ovšem obsahuje také stručný nárys dějin socialistického školství a metodologické pasáže, kde je popsán způsob využití orální historie v historicko-pedagogickém výzkumu včetně možných předností i úskalí takového zkoumání. Součástí knihy jsou navíc historické prameny, které jednak doplňují vzpomínky pamětníků, jednak ukazují, s jakými prameny se může historik setkat. Mnohé z publikovaných pramenů jsou zveřejněny vůbec poprvé. 